\title{
Article
}

\section{Knowledge and attitudes to prescription charges in New Zealand and England}

Norris, Pauline T, Wilson, Sarah E, Green, James A, Gu, Jessica, Goddard, Shelby, Deadman, Logan R, Dai, Jennefa, Fastier, Kelsi, Kothapally, Christina, Shi, Wendy, Whyte, Aleisha, Aslam, Haleema, Desai, Raeesa, Wood, Nicole and Sibley, Chris G

Available at http://clok.uclan.ac.uk/17363/

Norris, Pauline T, Wilson, Sarah E ORCID: 0000-0002-2875-0036, Green, James A, Gu, Jessica, Goddard, Shelby, Deadman, Logan R, Dai, Jennefa, Fastier, Kelsi, Kothapally, Christina et al (2018) Knowledge and attitudes to prescription charges in New Zealand and England. Research in Social \& Administrative Pharmacy, 14 (2). pp. 180-186. ISSN 1551-7411

It is advisable to refer to the publisher's version if you intend to cite from the work. http://dx.doi.org/10.1016/j.sapharm.2017.02.016

For more information about UCLan's research in this area go to http://www.uclan.ac.uk/researchgroups/ and search for <name of research Group>.

For information about Research generally at UCLan please go to http://www.uclan.ac.uk/research/

All outputs in CLoK are protected by Intellectual Property Rights law, including Copyright law. Copyright, IPR and Moral Rights for the works on this site are retained by the individual authors and/or other copyright owners. Terms and conditions for use of this material are defined in the policies page.

\section{CLoK}

Central Lancashire online Knowledge www.clok.uclan.ac.uk

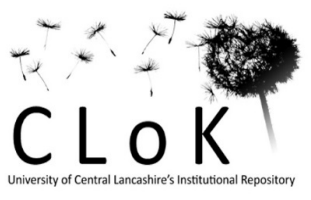




\section{Knowledge and attitudes to prescription charges in New Zealand and England}

\section{Abstract:}

Background: Prescription charge regimes vary between countries but there is little research on how much people know about these or support values underlying them.

Objective: To explore, in New Zealand (NZ) and England, the public's knowledge of, and attitudes to, charges and whether knowledge and attitudes varied by demographic characteristics or by values about entitlement to public goods.

Method: A questionnaire was developed and administered to people over 18 recruited in public places in NZ and England.

Results: 451 people in NZ and 300 people in England participated. Less than half in each country knew the current prescription charge. In each country $62 \%$ of people were unaware of arrangements to protect people from excessive annual charges. Support for free or lower cost medicines for children, people over 65 , people on low incomes, people on benefits, and people with chronic health problems was higher in England than in NZ. Support varied by participants' demographic characteristics and, in the case of people on low incomes and people on benefits, by values about universal entitlements.

Discussion: Gaps in knowledge, particularly about mechanisms to protect people from high costs, are concerning and may lead to people paying excessive charges. There was consensus about the elderly, children and the chronically ill being "deserving" of lower prescription charges, but people who did not believe in universal access to public goods appeared to see people on low incomes or benefits as less "deserving". In general, public views resembled those underlying the prescription charge regime in their country.

Key words: prescription charges, New Zealand, England, public views, public attitudes, comparative study 


\section{Knowledge and attitudes to prescription charges in New Zealand and England}

INTRODUCTION

Although governments in most industrialised countries pay most of the costs of prescription medicines for their citizens ${ }^{1}$, they also require citizens to contribute. Prescription charges generate revenue, and reduce excessive demand for and wastage of prescription medicines. However there is a considerable body of research and reviews $s^{2-4}$ showing that prescription charges prevent some people getting medicines they need ${ }^{2,5-10}$, increase utilisation of other health services ${ }^{11,12}$ and have a negative impact on people's health ${ }^{13,14}$. Thus prescription charges are an important aspect of the interface between consumers and health systems, and experiences of being unable to pay can significantly affect people's interactions with and perceptions of the health system ${ }^{7}$. Prescription charge regimes vary widely in different countries $^{15,16}$. This study examines two relatively similar countries, New Zealand and England, which currently have different approaches to prescription charges. New Zealand was a British settler colony, and most New Zealanders have European ancestry. Both countries have now ethnically diverse and New Zealand also has a significant indigenous population. Both countries have a health system funded predominantly through taxes and which aims to minimise financial barriers to healthcare. In both countries general practitioners (GPs) play a very significant role in providing primary healthcare, however in England GP visits are free, whilst in New Zealand there are significant user charges.

In New Zealand prescription charges are low, but are (almost) universally applied. Everyone 13 years and over pays $\$ 5$ (equivalent to $\$ 3.54$ USD on 1 Dec 2016) per prescription item. This entitles the patient to up to 3 months of a medicine. There are some other charges, for example for medicines that are only partially subsidised, but the standard charge for the great majority of medicines is $\$ 5$. There is a payment ceiling of 20 items per individual or family per year (1 Feb- 31 Jan). After this people can obtain a Prescription Subsidy Card that entitles them to be exempt from the standard $\$ 5$ charge ${ }^{17}$. However previous research has suggested that many people may continue to pay despite this ${ }^{18}$. 
In the UK, prescription charges vary by country. In Scotland, Wales and Northern Ireland prescriptions are free ${ }^{19}$. In England there is a standard charge, but most prescriptions are exempt $(89.9 \% \text { in } 2014)^{20}$. The charge is much higher than that in New Zealand (8.20 UK pounds at the time of the study, which is equivalent to 10.27 USD at $1 / 12 / 16)^{21}$ but is applied to a minority of prescriptions (and length of supply is longer (up to 6 months)). Exemptions are available on the basis of age (those under 16, those 16-18 in full-time education and those aged 60 or over), illness (those with a medical exemption certificate or who have a listed condition) and income (on Income Support or sometimes other benefits or tax credits). It is estimated that approximately half the adult population are exempted from charges ${ }^{22}$. As in New Zealand, there is also a system for protecting people from excessive annual charges. Those who require large numbers of prescriptions can purchase a Prescription Prepayment Certificate (PPC), that allows them to get as many prescription items as required, in the timeframe that they have prepaid for, reducing and capping the cost. $^{23}$

In NZ, apart from children, all citizens pay the same small amount for all prescriptions ${ }^{24}$. In England, those who may face a lot of prescription charges, either through age or ill-health are exempted from charges. These exemptions are very broadly applied so that, for example, individuals over 60 who are in very good health and take few medicines are also exempt from charges. In both countries there is some protection for those with poor health and therefore many prescription medicines in one year.

There is little research exploring what the general population know about prescription charges. Knowledge of entitlement is important because it is one of the factors that determines whether people access social support they are entitled to ${ }^{25}$. There is also little or no research on whether the public support the policy approaches to prescription charges taken in their country, with the notable exception of Schaftheutle ${ }^{26}$. Public support for the policy approach in their country could be because the system of prescription charges reflects commonly held moral values about who is entitled to free medicines (who is deserving or undeserving) or how subsidies should be targetted, or it could be that citizens of a country come to accept the system that they have and regard it as fair. Views about universality of access to essential items and services may also affect views of prescription 
charges and this may or may not vary between countries. Initiatives involving public involvement in decision making, such as structured dialogues in Canada, and citizen's juries in Australia have explored community values in relation to healthcare. In the Canadian process citizens opposed the introduction of user fees because of concerns about access ${ }^{27}$, and in Australia citizens were similarly concerned with equity ${ }^{28}$.

The aim of the study was to explore, in New Zealand and England, the general public's knowledge of and attitudes to prescription charges, whether this varied by demographic variables or by values about entitlement. An additional aim was to compare NZ and England, looking at whether knowledge, attitudes and their predictors were similar or different.

\section{METHODS}

A questionnaire was developed and administered to people recruited in public places in a range of cities and towns in New Zealand and England.

\section{Questionnaire design}

The questionnaire was designed to be short (2-5 minutes) and easy to administer in public places. The initial draft was developed by the New Zealand investigators, and then discussed by Skype with the England team, to identify questions which needed to be adapted for England (the ethnicity question and some of the prescription charges questions). The researchers in England then adapted these questions or response options to ensure that they made sense in the English setting.

Participants in both countries were asked the same questions about their age, gender and ethnicity. Response options for ethnicity were different in each country, with each based on the ethnicity question used in the national census. Participants were then asked their occupation, and to rate their health on a five point scale. 
The interviewer then asked the participant how much people usually pay for a prescription medicine, and a question about their knowledge of the exemption arrangements in their country. In New Zealand this was about the Prescription Subsidy Card available after 20 items, and in England it was about the Prescription Prepayment Certificate. Participants were then told the standard prescription charge in their country and asked whether they thought that a range of different people should pay that charge, less or nothing. They were then asked about the standard charge and whether they thought it should stay the same, be increased, or be decreased.

The final question asked participants for their opinion of the statement "Everyone has the right to food, housing and medicine". This item was adapted from McFarland and Mathews ${ }^{29}$ for use in the New Zealand Attitudes and Values Study ${ }^{30}$.

In New Zealand the initial questionnaire was pretested and adapted as necessary. Relevant changes were also adopted in the English version. This was pretested in England and no further changes were made.

\section{Interviews}

The questionnaire was administered to adults aged 18 years or older in public areas with high pedestrian traffic in 9 cities and towns around NZ in June/July 2015 and in Preston and Manchester in England in July 2015. Student interviewers selected locations based on their observations of pedestrian traffic. Interviews were conducted at a range of times in order to obtain a wide range of responses. These were all during working hours and daylight, to ensure student safety. In New Zealand researchers spent more than 35 hours and in England ..... Researchers approached the first person they saw in the public area and after checking that the person was aged 18 or older, invited them to participate. If the person declined, the next available person was asked. Once a participant agreed to participate, they were given an information sheet briefly summarising the aims of the study and were given a brief verbal summary of the information sheet. Questions were read to participants and their answers were recorded in writing on the questionnaire. 


\section{Analysis}

Data were entered into Excel (NZ) and into PSPP (England) ${ }^{31}$. Data entry was then cross checked by another researcher to ensure accuracy. All analyses were conducted using RStudio 0.99/R 3.2.2 32 , 33. Occupations were grouped into one of five categories; Employed, Unemployed, Retired, Student or Homemaker, and then dummy coded (using "Employed" as reference). For analyses using ethnicity in England, Arabs $(n=3)$ were excluded because of small group size. Ethnicity was otherwise dummy coded (England: White, NZ: Pakeha (NZ European) as reference). Age was dummy coded (18-24 reference), along with gender (female reference). Health status and responses to the value statement were treated as continuous predictors. (Those that strongly agreed with the values statement, and those in excellent health were the reference group).

For binary outcomes (NZ: knowledge of prescription service card, and that it applied to families; England: awareness of prescription prepayment certificate), logistic regression was used. Knowledge of the prescription price was also treated as binary (knows correct price/does not know correct price). Linear regression was used for the Likert type (values statement). To analyse the relationship between demographic variables or values statement and opinions about what each group of people (e.g. those on benefits) should pay for prescriptions, "the usual charge" was coded as "1", "a lower charge" as "2" and "free" as " 3 " to produce a quasi-interval scale where higher scores indicate stronger belief in entitlement to free prescription medicines. For each variable people who said they were "not sure" were omitted. One person who said that people on benefits should be charged more was recoded to "usual cost" for analysis.

\section{Ethical approval}

In NZ ethics approval was granted by the School of Pharmacy acting under delegated authority from the University of Otago Human Ethics Committee (reference number SoP0915). In England ethical approval was granted by the UCLAN Ethics Committee (STEMH352). 


\section{RESULTS}

451 people completed the questionnaires in NZ, out of 678 people who were approached. (Response rate=67\%). 300 people completed the questionnaire in England, but unfortunately response rate was not recorded. Participant demographics and self-rated health are presented in Table 1.

The New Zealand and England samples were strikingly similar in terms of gender, but the England sample tended to be younger. In both countries the sample was a reasonably good representation of the population in terms of ethnicity (although in both cases there was an over-representation of Asian people) $)^{34}$. Occupations were also similar although there were more students in the England sample. The proportion of people rating their health status as fair or poor was much higher in New Zealand.

Knowledge of prescription chargesIn New Zealand 46\% of participants (207 people) knew that the usual cost was $\$ 5.00$. Age, gender, ethnicity and occupation were significantly related to this. Those over $65(\mathrm{OR}=1.9(\mathrm{Cl}=1.02-3.5))$, NZ Europeans $(\mathrm{OR}=1.29(\mathrm{Cl}=1.01$ 1.65)), and those who were retired $(\mathrm{OR}=2.98(\mathrm{Cl}=1.59-5.88))$ were most likely to know the usual cost, while men were less likely than women to know the usual cost $(O R=0.64(C)=$ 0.44-0.93)

In England, the majority of the participants (281 (94\%)) were not aware of the exact cost of a prescription item. Since the charge is not a round number as it is in New Zealand a more flexible definition of a "correct answer" (anything between 8 pounds and 8.50 pounds) was used. One hundred and three people (34\%) answered within this range. This broader definition was used in the rest of the analyses. Gender, ethnicity, and self-reported health 
status were significant. Men $(O R=0.44(C l=0.26-0.72)$, people of Asian or British Asian ethnicity $(\mathrm{OR}=0.05(\mathrm{Cl}=0.25-0.97))$, and people with higher self-reported health $(0.60$, $\mathrm{Cl}=0.44-0.80$ ) were the least likely to know the cost.

Sixty two percent of people (279) in New Zealand did not know that they should only have to pay for up to 20 prescription items per year. Of those that knew this, $28 \%$ (48 people) did not know that this applies to a family. Age, gender, ethnicity and occupation were predictors. Compared to $18-24$ year olds, the 45-64 age group were 1.8 times as likely to know about it $(\mathrm{Cl}=1.02-3.23)$ and those 65 years and over more than 4 times as likely to know about it $(O R=4.17(2.22-8.02))$. Men were also less likely to know about the subsidy card, with only $31 \%$ knowing compared with $43 \%$ of women. Māori (23.6\%), Pacific people (19.4\%) and Asians (27.9\%) were much less likely to know about the card than NZ Europeans (47\%). Retired participants were significantly more likely to know about the subsidy card $(\mathrm{OR}=6.85(\mathrm{Cl}=3.63-13.62))$, with $75 \%$ of them knowing about it.

In England 62\% of the participants (184 people) were not aware of the Prescription Prepayment Certificate. Age was related to being aware of this. Those aged 45-64 (OR=5.38, $\mathrm{Cl}=2.59-11.68)$, and retired people $(\mathrm{OR}=2.62(\mathrm{Cl}=1.13-6.45))$ were most likely to know about the PPC. Ethnicity was related to this, but not significantly, with white people being most likely to know about it.

\section{Values question}

Answers given to the question: "Do you agree or disagree with the statement: Everyone has the right to food, housing and medicine?" in New Zealand, England and in the New Zealand Values study, from which it is taken, are reported in Figure 1. Responses from all three groups show a similar pattern. Larger proportions of both the NZ and England arms of this study strongly agreed with the statement than the NZ Values study. Larger proportions of our participants also chose the middle, neutral option. 
In NZ, responses to the values statement were significantly related to gender and ethnicity. Men $(\bar{X}=5.8)$ were less likely to agree with the statement "everyone has the right to food, housing and medicine" compared with women $(\bar{X}=6.2)(p=0.009)$. Those participants identifying as Māori ( $\bar{X}=6.6)$ agreed with this statement more than NZ Europeans $(\bar{X}=6.1)$ ( $p$ $=0.02)$, whereas those identifying as Pacific $(\bar{X}=5.2)$ or Asian $(\bar{X}=5.6)$ were less likely to agree $(p<.001$ and $p=0.02$ respectively). In England, age and employment status were related to responses. $69 \%$ of $18-24$ year olds strongly agreed with the statement compared to $53 \%$ and $50 \%$ in the two older categories. $89 \%$ of unemployed people compared to $60 \%$ of employed people strongly agreed $(p=0.02)$.

\section{Views about prescription charges}

As outlined in Table 2, most participants in both countries thought that prescriptions should be free for children under 13, but the proportion was much higher in England. Most respondents in England (70\%) thought that people over 65 should pay nothing compared to only $39 \%$ of those in New Zealand. A far greater proportion of New Zealanders thought people on low incomes should pay the usual prescription charge ( $29 \%$ vs $9 \%$ ). Only $23 \%$ of New Zealanders but $37 \%$ of people in England thought prescriptions should be free for this group. A similar pattern held for people on benefits: more New Zealanders thought people on benefits should pay the usual charges, and more English respondents thought prescriptions should be free for people on benefits. Similarly, support for free prescriptions for people with chronic health problems was much higher in England.

The majority of New Zealanders (60\%) supported the current level of prescription charges in New Zealand. 31\% thought it should be reduced, and 3\% thought it should be increased. Fewer people in England supported the current level of prescription charges: sixty-three percent thought the charge should be reduced, and $1 \%$ thought it should be increased. Six percent in New Zealand and 11\% in England were not sure. 
Table 3 shows the relationship between demographic variables and values, and views about which population groups should pay for prescriptions.

In New Zealand, unemployed people were more likely to support children having cheaper (or free) prescriptions $(M=2.8), p=.009$. Those that strongly disagreed with the values statement $(M=2.4)$ were less likely to agree that children should have cheaper prescriptions $p=.006$. Those aged 25-44 were more likely to support cheaper prescriptions $(\bar{X}=2.3)(p=0.009)$ for the elderly. Those who strongly disagreed with the values statement $(M=1.5)$ were less likely to support cheaper prescriptions for those on benefits. $(p<0.001)$. Those of Asian ( $\bar{X}=2.1)(p=0.03)$, and Other $(\bar{X}=2.2)(p=0.03)$ ethnicities were more likely to support cheaper prescriptions for those with low incomes. The unemployed ( $\bar{X}=2.2)$, ( $p$ $=0.03$ ) were more likely to support cheaper prescriptions for those with low incomes. Those that strongly disagreed with the values statement $(\bar{X}=1.6)$, were less likely to support cheaper prescriptions for those on benefits $p=<0.03$. Those of Other Ethnicities supported lower prescription charges for those with chronic illness $(\bar{X}=2.6) p=0.02)$. Those in the poorest health $(M=1.8)$ were more generous $p<.001$.

In England, those aged 45-64 ( $\bar{X}=3.0)$ were unanimous in their belief that prescriptions should be free for children ( $p=0.02)$. British Asians were less likely to agree $(\bar{X}=2.8)(p=0.04)$. The mean for Black Minority Ethnic (BME) people ( $\bar{X}=2.5$ ) was lower, (although the number in this group was low) $(p=<0.001)$. Those aged 25-44 were more likely to support cheaper prescriptions $(\bar{X}=2.8)(p=0.003)$ for retired people. The mean for those over 65 was 2.9 $(p=0.03)$. Asian/British Asian were less likely to support cheaper prescriptions for elderly people $(\bar{X}=2.6)(p=0.04)$. Students were less supportive of cheaper prescriptions for elderly people $(\bar{X}=2.6)(p=0.03)$. Those aged 45-64 ( $\bar{X}=2.5)(p=0.001)$, and those over $65(\bar{X}=2.4)$ $(p=0.03)$ were more likely to support cheaper prescriptions for those on benefits. Retired people $(\bar{X}=2.5),(p=0.009)$ and the unemployed $(\bar{X}=2.6),(p=0.02)$ were more likely to support cheaper prescriptions for those on benefits. Those that strongly disagreed with the values statement $(\bar{X}=1.8)$, were much less likely to support cheaper prescriptions for those on benefits $p=<0.001$. Older people (45- 64 year olds and those over 65 ) were more likely to 
support cheaper prescriptions for those on low incomes $(p=0.02$ and $p=0.04)$. The retired (2.6) $(p=0.004)$, and unemployed $(\bar{X}=2.7)(p=0.005)$, were more generous about those on low incomes. Those who strongly disagreed with values statement were much less likely to support cheaper prescriptions $(p=<0.001)$. Those aged 45-64 were more generous $(\bar{X}=2.9)$ $p=0.02$ ) about cheaper prescriptions for those with chronic illnesses.

\section{DISCUSSION}

In each country, less than half the population knew about the usual charge for prescriptions, although the proportion was higher in New Zealand. In each country, the majority of people did not know about the system in place to protect them from high prescription charges. In New Zealand older people, women and NZ Europeans were more likely to know about it. In England older people were also the most likely to know about the system. Support for free prescriptions for children, older people, people on low incomes or benefits, and people with chronic health problems was higher in New Zealand than in England. Participants' demographic characteristics were related to whether they supported free prescriptions for these groups. Participants' values also affected their support for free prescriptions for people on low incomes and people on benefits.

The limitations of the study include non-random samples. Approaching people in the street is likely to lead to an over-representation of some groups, and under-representation of others. For example, people who are home-bound would not have been included. It is possible that people who refused to participate may have differed from those who agreed. The sample included more females than males, however people from a range of ages and ethnic backgrounds were included. We did not ask people in England whether they were exempt from prescription charges (and obviously this is likely to affect their knowledge of charges). People may also respond differently when faced with hypothetical questions rather than real situations. When asking about how much different groups should pay, participants were not asked whether they thought any groups should pay more than they currently do (although they were asked whether the usual charge should be higher). In addition, participants were not asked how much money they thought people should pay. Instead answers were defined in terms of the usual copayment in each country, so "less 
than usual" in England, could be the same amount as usual in NZ. Finally, one question is not a comprehensive way to measure people's values.

Accurate knowledge of the cost of prescriptions items seems predictable based on the schemes in each country and patterns of pharmacy usage. In New Zealand older people and those retired were more likely to know the cost, presumably because of high prescription medicine use which they have to pay for. In England this was not the case because elderly people there do not have to pay for their medicines. In both countries men were less likely to know the cost, presumably because they are less likely to visit pharmacies because of gender roles and lower medicines use ${ }^{35,36}$. In both countries Asians were less likely to know the cost, and the reason for this is unclear.

An identical proportion of people in each country, a majority of the sample, did not know about the scheme designed to protect people from high prescription charges. This is consistent with previous qualitative research in England ${ }^{22}$ and suggests that these schemes may not be working well. Although such schemes should not rely entirely on patient knowledge to be initiated, public knowledge is important to ensure that entitlements are accessed by those who are eligible ${ }^{25}$. Not surprisingly, in New Zealand older people and retired people were more likely to know about the scheme. In England, the age group who are most likely to face many prescriptions charges, the 45-64 age group, were also the most likely to know about it. In both countries men were less likely to know about it. The findings by ethnicity are concerning. In both countries white participants were most likely to know about the scheme. Although the difference was not statistically significant in England, it was large and statistically significant in New Zealand. Given that Māori and Pacific people have lower health status and are more likely to report going without medicines because of $\operatorname{cost}^{5}$, this is a worrying finding. McMillan et al in Australia found that some consumers were unaware of how the Pharmaceutical Benefits Scheme worked and how to access higher prescription subsidies ${ }^{37}$. Some pharmacists who participated in McMillan et al.'s study reported that some consumers who should be eligible to reach the threshold for cheaper prescriptions missed out on this because they used various pharmacies and did not keep a record of all their prescriptions ${ }^{38}$. In other settings, lack of knowledge of entitlements and how to claim them has been identified as a problem ${ }^{39}$. Other studies have also found gaps in 
knowledge of entitlements amongst ethnic minority populations ${ }^{40}$. For example, a New Zealand study found that non-European New Zealanders were less likely to know about the meals on wheels service ${ }^{41}$.

Predictors of values were different in each country: gender and ethnicity were important in NZ, age and employment status in England. Reasons for this are unclear. Support for free or cheaper prescriptions for any group was higher in England than in New Zealand, suggesting that prescription charge regime and population values align in each country. In both countries support was strongest for free or cheaper prescriptions for children and weakest for people on low incomes or benefits.

While responses to questions about the ideal rate of prescription charges for all groups were influenced by demographic characteristics of respondents, responses to the values statement were also significant for views about how much people on benefits and people on low incomes should pay. Perhaps there is greater social consensus about the elderly, children and the chronically ill being "deserving" of greater assistance. People on low incomes and those on benefits might be seen as "undeserving" by people who do not believe in universal access to necessities of life. This results also supports the validity of this measure of attitudes to human rights or "Identification with all humanity" 42

\section{Conclusion}

In general people's views in each country do appear to support the systems they have, and thus systems seem to reflect underlying values about entitlement. While it is not unexpected that people who interact most with the pharmacy system are most familiar with information about usual prices of medicines, it is concerning that lack of knowledge of entitlements is low in groups who tend to have lower health status.

\section{References}

1. OECD. "Pharmaceutical expenditure", in Health at a Glance 2011: OECD Indicators: OECD Publishing; 2011. 
2. Rice T, Matsuoka K. The Impact of Cost-Sharing on Appropriate Utilization and Health Status: A Review of the Literature on Seniors. Medical Care Research and Review. 2004;61:415-452.

3. Lexchin J, Grootendorst P. Effects of prescription drug user fees on drug and health services use and on health status in vulnerable populations: a systematic review of the evidence. International journal of health services. 2004;34:101-122.

4. Austvoll-Dahlgren A, Aaserud M, Vist G, et al. Pharmaceutical policies: effects of cap and copayment on rational drug use (review). Cochrane Database of Systematic Reviews. 2008:119.

5. Jatrana $S$, Crampton $P$, Norris $P$. Ethnic differences in access to prescription medication because of cost in New Zealand. JECH. 2010;65:454-460.

6. Atella V, Schafheutle E, Noyce P, Hassell K. Affordability of Medicines and Patients' Costreducing Behaviour. Applied Health Economics and Health Policy. 2005;4:23-36.

7. Norris P, Tordoff J, McIntosh B, Laxman K, Chang SY, Te Karu L. Impact of prescription charges on people living in poverty: A qualitative study. Research in Social and Administrative Pharmacy.

8. Soumerai S, Avorn J, Ross-Degnan D, Gortmaker S. Payment restrictions for prescription drugs under Medicaid. Effects on therapy, cost, and equity. N. Engl. J. Med. 1987;317:550556.

9. Stuart B, Grana J. Ability to Pay and the Decision to Medicate. Medical Care. 1998;36:202211.

10. Dana G, Neuman P, Schoen C, et al. Prescription drug coverage and seniors: Findings from A 2003 national survey. Health Affairs. 2005;24:152-166.

11. Goldman D, Joyce G, Zheng Y. Prescription Drug Cost Sharing: Associations With Medication and Medical Utilization and Spending and Health. JAMA. 2007;298:61-69.

12. Heisler $\mathrm{M}$, Choi $\mathrm{H}$, Rosen $\mathrm{A}$, et al. Hospitalizations and deaths among adults with cardiovascular disease who underuse medications because of cost: A longitudinal anlaysis. Medical Care. 2010;48:87-94.

13. Jatrana S, Richardson $K$, Norris $\mathrm{P}$, Crampton $\mathrm{P}$. Is cost-related non-collection of prescriptions associated with a reduction in health? Findings from a large-scale longitudinal study of New Zealand adults. BMJ Open. 2015;5.

14. Heisler M, Langa KM, Eby EL, Fendrick AM, Kabeto MU, Piette JD. The Health Effects of Restricting Prescription Medication Use Because of Cost. Medical Care. 2004;42:626-634.

15. Noyce PR, Huttin C, Atella V, et al. The cost of prescription medicines to patients. Health Policy. 2000;52:129-145.

16. Exective S. Review of prescription charges in Western Europe, North America and Australasia 2006.

17. Ministry of Health New Zealand. Prescription Subsidy Card. Vol 2015. Wellington: Ministry of Health New Zealand,; 2015.

18. Norris $\mathrm{P}$, Horsburgh $\mathrm{S}$, Cumming J. Press release: Kiwis missing out on free prescription medicines entitlement2012.

19. News B. Prescription charges abolished in Scotland. Vol 2016: BBC News; 2011.

20. Health and Social Care Information Centre. National Statistics: Prescriptions Dispensed in the Community, Statistics for England - 2004-2014. Vol 20162015.

21. National Health Service. Help with health costs - Get help with prescription costs Vol 20152015.

22. Schafheutle El, Hassell K, Noyce PR. Access to medicines: cost as an influence on the views and behaviour of patients. Health \& social care in the community. 2002;10:187-195.

23. National Health Service. Help with health costs - Did you know you can save money with a prescription prepayment certificate (PPC)? 2014 [updated 2014 Apr 01; cited 2015 Sep 27]. Available from: http://www.nhs.uk/NHSEngland/Healthcosts/Pages/PPC.aspx. Vol 20152014. 
24. New Zealand Government. 2014 Buget Speech. Vol 2015. Wellington: New Zealand Treasury; 2014.

25. Department for Work and Pensions. Income-Related Benefits: Estimates of Take-up Financial Year 2013/14 (experimental) London: Department for Work and Pensions; 2015.

26. Schafheutle El. Patients' views on the UK policy of prescription charges-Insights from qualitative interviews. Research in Social and Administrative Pharmacy. 2008;4:343-354.

27. Maxwell J, Rosell S, Forest P-G. Giving citizens a voice in healthcare policy in Canada. BMJ. 2003;326:1031-1033.

28. Mooney G, Blackwell S. Whose health service is it anyway? Community values in healthcare. Med J Aust. 2004;180:76-78.

29. McFarland S, Mathews M. Who Cares About Human Rights? Political Psychology. 2005;26:365-385.

30. Sibley CG, Greaves LM. NZAVS content rotation and planning document. . NZAVS Technical Documents. Vol e02. Auckland, New Zealand2014.

31. Project G. GNU PSPP for GNU/Linux (Version 0.8.5) Boston, MA: Free Software Foundation; 2015.

32. Team R. RStudio: Integrated Development for R. Boston, MA: RStudio, Inc.; 2015.

33. R Core Team. R: A language and environment for statistical computing. Vienna, Austria: $R$ Foundation for Statistical Computing; 2016.

34. Wikipedia. https://en.wikipedia.org/wiki/Demography of England\#Ethnicity. Vol 2015.

35. Manteuffel M, Williams S, Chen W, Verbrugge RR, Pittman DG, Steinkellner A. Influence of Patient Sex and Gender on Medication Use, Adherence, and Prescribing Alignment with Guidelines. Journal of Women's Health 2014;23:112-119.

36. Boardman $\mathrm{H}$, Lewis $\mathrm{M}$, Croft $\mathrm{P}$, Trinder $\mathrm{P}$, Rajaratnam $\mathrm{G}$. Use of community pharmacies: a population-based survey. Journal of Public Health. 2005;27:254-262.

37. McMillan S, Kelly F, Sav A, King M, Whitty J, Wheeler A. Consumer and carer views of Australian community pharmacy practice: awareness, experiences and expectations. Journal of Pharmaceutical Health Services Research. 2014;5:29-36.

38. McMillan S, Kelly F, Sav A, et al. Consumers and Carers versus Pharmacy Staff: Do their priorities for Australian Pharmacy Services align? Patient. 2014.

39. Moffatt $S$, Noble E, Exley $C$. "Done more for me in a fortnight than anybody done in all me life." How welfare rights advice can help people with cancer. BMC Health Services Research. 2010;10:1-12.

40. Ahmad WIU, Walker R. Asian Older People: Housing, Health and Access to Services. Ageing \& Society. 1997;17:141-165.

41. Wilson A, Dennison K. Meals on wheels service: Knowledge and perceptions of health professionals and older adults. Nutrition \& Dietetics. 2011;68:155-160.

42. McFarland S, Webb M, Brown D. All Humanity Is My Ingroup: A Measure and Studies of Identification With All Humanity. Journal of Personality and Social Psychology. 2012. 
Table 1: participant demographic data

\begin{tabular}{|c|c|c|c|c|c|}
\hline & & $\begin{array}{l}\text { New } \\
\text { Zealand }\end{array}$ & & England & \\
\hline & & Number & Percent & Number & Percent \\
\hline \multirow[t]{2}{*}{ Gender } & Male & 193 & 43 & 132 & 44 \\
\hline & Female & 258 & 57 & 168 & 56 \\
\hline \multirow[t]{4}{*}{ Age } & $18-24$ & 91 & 20 & 105 & 35 \\
\hline & $25-44$ & 151 & 33 & 124 & 41 \\
\hline & $45-64$ & 129 & 29 & 47 & 16 \\
\hline & $65+$ & 80 & 18 & 24 & 8 \\
\hline \multirow{5}{*}{$\begin{array}{l}\text { Ethnicity } \\
(\mathrm{NZ})^{1}\end{array}$} & New Zealand European & 269 & 58 & & \\
\hline & Māori & 53 & 11 & & \\
\hline & Pacific & 31 & 7 & & \\
\hline & Asian & 86 & 19 & & \\
\hline & Other & 25 & 5 & & \\
\hline \multirow{5}{*}{$\begin{array}{l}\text { Ethnicity } \\
\text { (England) }\end{array}$} & White & & & 224 & 74 \\
\hline & Mixed or multiple ethnicity & & & 8 & 2 \\
\hline & Asian or British Asian & & & 56 & 19 \\
\hline & $\begin{array}{l}\text { Black/African/Caribbean/Black } \\
\text { British }\end{array}$ & & & 9 & 3 \\
\hline & Arab or other ethnic group & & & 3 & 1 \\
\hline \multirow[t]{5}{*}{ Occupation } & Employed & 279 & 62 & 184 & 61 \\
\hline & Retired & 56 & 12 & 26 & 9 \\
\hline & Unemployed & 27 & 6 & 18 & 6 \\
\hline & Studying & 67 & 15 & 72 & 24 \\
\hline & Homemaker & 22 & 5 & & \\
\hline $\begin{array}{l}\text { Self-rated } \\
\text { health }\end{array}$ & 1 (ie excellent) & 73 & 16 & 42 & 14 \\
\hline
\end{tabular}




\begin{tabular}{|l|l|l|l|l|l|}
\hline & 2 & 148 & 33 & 139 & 46 \\
\hline & 3 & 124 & 27 & 93 & 31 \\
\hline & 4 & 55 & 13 & 24 & 8 \\
\hline & 5 (poor) & 51 & 11 & 2 & 1 \\
\hline
\end{tabular}

${ }^{1}$ The main ethnic groups identified in the New Zealand census are New Zealand European (New Zealanders who trace their ancestry to people from Europe), Maori (indigenous New Zealanders), Pacific (people who trace their ancestry to Pacific Island countries such as Samoa, Tonga, Fiji etc), Asian (people who trace their ancestry to Asian countries, including the Indian subcontinent, such as China, India, Pakistan, Vietnam), and Other ethnic groups.

Figure 1: responses to the values question: "Do you agree or disagree with the statement:

Everyone has the right to food, housing and medicine?" 
Table 2: Views about how much people should pay for prescriptions in New Zealand and England (\% of respondents in each country)

\begin{tabular}{|c|c|c|c|c|c|c|c|c|}
\hline & \multicolumn{2}{|c|}{$\begin{array}{l}\text { Should pay the } \\
\text { standard charge }\end{array}$} & \multicolumn{2}{|c|}{$\begin{array}{l}\text { Should pay } \\
\text { less }\end{array}$} & \multicolumn{2}{|c|}{$\begin{array}{l}\text { Should get } \\
\text { free } \\
\text { prescriptions }\end{array}$} & \multicolumn{2}{|c|}{ Not sure } \\
\hline & $\mathrm{NZ}$ & England & $\mathrm{NZ}$ & England & $\mathrm{NZ}$ & England & $\mathrm{NZ}$ & England \\
\hline $\begin{array}{l}\text { Children under } 13 \\
\text { (currently free in } \\
\text { both countries) }\end{array}$ & 16 & 1 & 24 & 9 & 55 & 88 & 4 & 2 \\
\hline $\begin{array}{l}\text { People over } 65 \\
\text { (currently free in } \\
\text { England) }\end{array}$ & 31 & 2 & 26 & 23 & 39 & 70 & 4 & 5 \\
\hline $\begin{array}{l}\text { People on low } \\
\text { incomes } \\
\text { (currently mostly } \\
\text { free in England) }\end{array}$ & 29 & 9 & 43 & 50 & 23 & 37 & 4 & 4 \\
\hline $\begin{array}{l}\text { People on benefits } \\
\text { (currently mostly } \\
\text { free in England) }\end{array}$ & 33 & 20 & 39 & 36 & 22 & 37 & 5 & 7 \\
\hline $\begin{array}{l}\text { People with long- } \\
\text { term chronic illness } \\
\text { (currently mostly } \\
\text { free in England) }\end{array}$ & 20 & 2 & 32 & 24 & 43 & 70 & 6 & 4 \\
\hline
\end{tabular}


Table 3: mean scores for what different population groups should pay for prescriptions

\begin{tabular}{|l|l|l|l|l|}
\hline & New Zealand & $\begin{array}{l}\text { Significantly } \\
\text { related to }\end{array}$ & England & $\begin{array}{l}\text { Significantly } \\
\text { related to }\end{array}$ \\
\hline Children & 2.4 & $\begin{array}{l}\text { Employment, } \\
\text { values }\end{array}$ & 2.9 & Age, ethnicity \\
\hline Over 65/retired & 2.1 & Age & 2.7 & $\begin{array}{l}\text { Age, ethnicity, } \\
\text { employment } \\
\text { status }\end{array}$ \\
\hline Benefits & 1.9 & Values & 2.2 & $\begin{array}{l}\text { Age, } \\
\text { employment, } \\
\text { values }\end{array}$ \\
\hline Low income & 1.9 & $\begin{array}{l}\text { Ethnicity, } \\
\text { employment, } \\
\text { values }\end{array}$ & 2.3 & $\begin{array}{l}\text { Age, } \\
\text { employment, } \\
\text { values }\end{array}$ \\
\hline People with \\
chronic illness
\end{tabular}

* "the usual charge" was coded as " 1 ", "a lower charge" as " 2 " and "free" as " 3 " to produce a quasi-interval scale where higher scores indicate stronger belief in entitlement to free medicine. People who said they were "not sure" were excluded. 